\title{
Mallards do Dive
}

\section{by Douglas E. Wade and Dorothy R. Wade, Regina}

The phenomenon of Mallards diving has been witnessed this winter on the open waters of the Wascana Waterfowl Park in Regina by several observers. On December 13, 1960, we observed a group of six Mallards diving. On other visits-December 23, 25, 27 (1960) and January 1, 2 and 14 (1961) - we observed groups of Mallards diving. Dr. Isabel Coleman also observed the diving on December 26. Diving appeared to increase when the shallower water became iced over. Most of the 300 or more Mallards (both sexes) seen on January 2 were diving.

The Mallard dives awkwardly compared with the true divers. It throws up some splash behind as it works its way under. This splashing is distinctive. Using the method of counting from 101,102 , etc. to estimate the number of seconds, we noted that the time under water varied from one to 11 seconds, the most frequent being seven seconds. Times were checked for at least 50 Mallards. A hen Mallard held the record of 11 seconds, but several males were under at least 10 seconds. The longest distance travelled under water was estimated to be seven feet. The precise depth of water where the birds were diving was not determin- ed, but we believe the depth varies from about $1 \frac{1 / 2}{2}$ to five feet.

Although we have not yet seen food in the bills of the diving Mallards, we believe the activity is associated with feeding. We have seen the tip-up or dabbling action going on in shallow water while Mallards in deeper water were diving. The presence of more than 600 Mallards wintering on the Wascana may have depleted the food supply in the shallow water.

A cursory examination of the literature reveals little information on the diving of Mallards. A. C. Bent in Life Histories of North American Wild Fowl (1923) states that "mallards .... escape (enemies) by diving and clinging motionless to weeds more often than attempting to swim long distances under water." Another dabbler, the Gadwall, dives if necessary for food (R. Pough, Audubon Water Bird Guide, 1951, p. 81).

Present at the Wascana Waterfowl Park during December, 1960, and January, 1961, were such excellent divers as Buffleheads, Ruddy Ducks, Lesser Scaup, Common Goldenieyes, and Pied-billed Grebes. Whether or not water birds learn certain activities by association has been little explored.

\section{Apparent Escape Behaviour of a Red-Breasted Nuthatch}

by R. W. Nero. Sask. Museum of Natural History.

The Red-breasted Nuthatch (Sitta canadensis) was surprisingly uncommon in the Uranium City area of Saskatchewan during May, June and July, 1960. While walking along a lightly-forested ridge south of Lorado Uranium Mine on the morning of May 14 I heard its characteristic call from a solitary white spruce on a rocky slope supporting mainly aspen and jack pine. However, since this species had only been recorded a few times for the area I was anxious to identify it by sight. I came upon the nuthatch quite suddenly and evidently surprised it. At once, and before I could get a good look at it, it scrambled out of sight and was silent. I walked around the tree, squeaking on the back on my hand to draw it out, but was unable to find it. Yet, since the tree stood quite by itself I was positive that the nuthatch had not flown. Suddenly I was surprised to see what appeared to be a dead bird, perfectly motionless and dangling from a horizontal branch about 12 feet above the ground. At first I felt sure that it was a dead warbler entrapped by its feet and hanging downward. I moved labout the tree in some elation, thinking to secure a specimen, and in order to identify it first, raised my binaculars. At that precise moment the "dead" bird moved slightly, hardly altering its position, and at once I realised it was a nuthatch, hanging by its toes, head and neck downward at full length, with its breast facing me; 


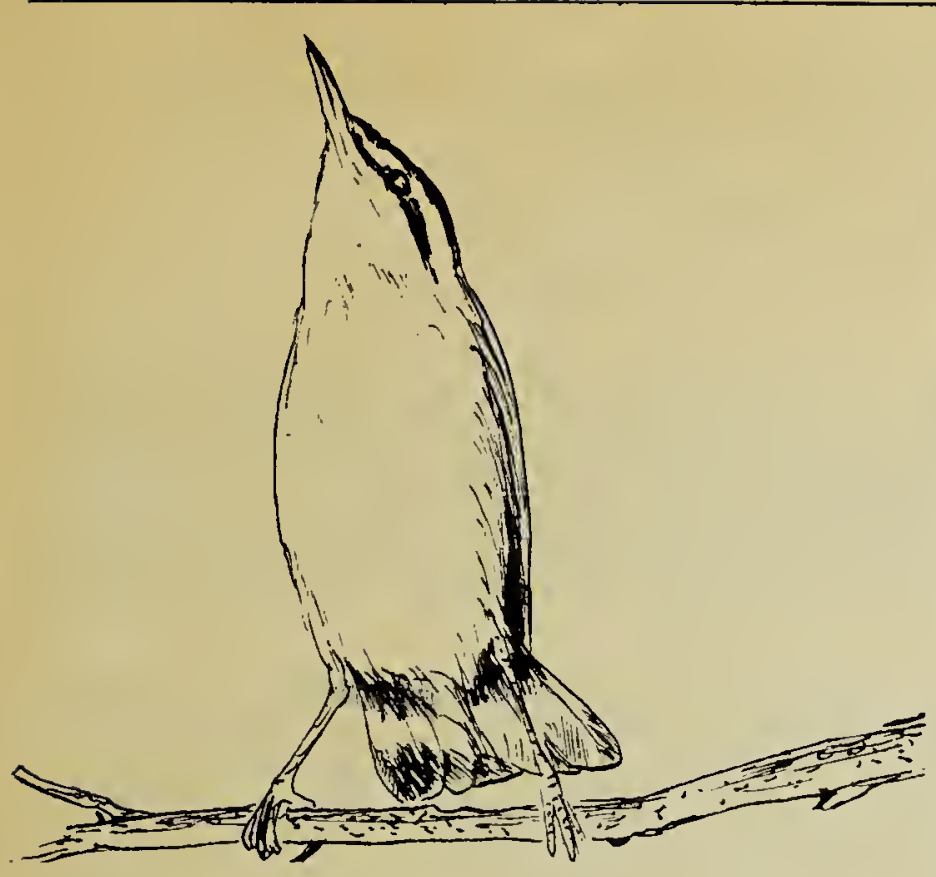

Drawing by Fred W. Lahrman. S.M.N.H.

what I had mistakenly taken to be the back of a warbler was actually the underparts of the nuthatch. In a moment it shook itself, as if suddenly recovering from some strain, as birds do, then began feeding in its usual manner. After a few seconds it flew away from the tree.

"Freezing" behaviour is not uncommon in birds and the protective value of remaining motionless in the presence of a predaitor is clear. I had at first overlooked the nuthatch right in front of my eyes, and found it only after some effort. I presume that nuthatches would not ordinarily react in this way to a human, but the surprise of unexpected appearance must have triggered this reaction. It seems peculiar for a bind to adopt the upside-down pasition for sudiden "freezing," but this position, of course, is characteristic of nuthatches.

Mrs. Louise de Kiriline Lawrence, Rutherglen, Ontario, has done considerable work with Red-breasted Nuthatches (see, for example, her "Irrepressible Nuthatch" in Audubon Book of True Nature Stories, 1958, Thomas Y. Crowell Co., New York), but she has not observed nuthatch behaviour as described above (pers. corres., 1960). However, she recalled somewhat similar behaviour in a Black-capped Chickadee:

"Many years ago I had an experience with a chickadee which, although not quite similar to yours, nevertheless immediately brought it to my mind. I was approaching the nest of a pair of chickadees to check just as the young were emerging. The parents became very upset. One of them flew toward me, but instead of attacking it alighted on a horizontal branch in front of me. Here it proceeded to swing itself down, as if falling, but holding fast with its feet, then swinging itself back into upright position again. This was done a number of times all along the branch, a perfectly fascinating performance of ups and downs.

"In this case it was obviously a distraction display. Apparently it was as natural for the chickadee to include the upside-down performance in its display as it was for your nuthatch, although in our minds neither display is commonly associated with this attitude."

\section{KINGFISHER ESCAPE TACTICS}

\section{by R. W. Nero, Sask. Museum of Natural History}

Recently, Thomas Heaslip submitted to me his records of bird observations made near Uranium City, Saskatchewan, from 1956 to 1960 (see Blue Jay, 17:57-58; Heasilip's present address: Loughries, Newtownards, Co. Down, N. Ireland). Among his notes there is included a description of behaviour in a Belted Kingfisher (Megaceryle alcyon) which closely resembles observations previously described for this species (Nero, R., 1949. Escape behaviour of a Kingfisher. Passenger Pigeon, 11:132). On July 14,1959 , Heaslip watched a Kingfisher hovering over a small lake near Lorado Mine. Suddenly, he writes, a Sparrow Hawk (Falco sparverius) appeared and closely pursued the Kingfisher. The latter dived down to the level of the water and then repeatedly plunged into it ("broke the surface"), each time sending up a shower of spray in front of the hawk, which finally gave up the chase. The earlier report describes a situation in which an aggressive male Redwinged Blackbird chased a Kingfisher until deterred in a similar way. In both of these cases the pursuer would appear to have been more of an annoyance than a danger. This suggests that these evasive tactics of the Kingfisher may be limited to encounters of this sort. 